\title{
SESJA JUBILEUSZOWA KU UCZCZENIU 5O-LECIA PRACY NAUKOWEJ KS. PROF. DR WEADYSŁAWA WICHRA
}

Staraniem, między innymi, Polskiego Towarzystwa Teologicznego w Krakowie odbyła się w dniu 25 stycznia 1969 r. w auli Krakowskiego Seminarium Duchownego uroczysta sesja naukowa poświęcona dorobkowi naukowemu ks. prof. dra Władysława Wichra. Sesja zorganizowana została ku uczczeniu 50-lecia jego pracy naukowo-dydaktycznej.

Po odśpiewaniu kantaty przez chór alumnów Krakowskiego Seminarium Duchownego przemówienie inauguracyjne wygłosił ks. prof. dr Stanisław Grzybek. Ks. Dziekan podkreślił zasługi Jubilata dla teologii moralnej a zarazem w imieniu wszystkich złożył mu najserdeczniejsze życzenia.

Referat omawiający działalność naukową ks. prof. Wichra wygłosił J. Em. Ks. Kard. Karol Wojtyła. Naprzód pokrótce zapoznał z curriculum vitae dostojnego Jubilata. Ks. prof. dr Władysław Wicher urodził się 22 stycznia 1888 r. w Krzyszkowicach, pow. Myślenice. Po złożeniu matury w gimnazjum Nowodworskiego w Krakowie, wstąpił w r. 1908 do Krakowskiego Seminarium Duchownego. Święcenia kapłańskie otrzymał z rąk ks. bpa Adama Sapiehy w r. 1912. Studia teologiczne odbywał najpierw na Wydziale Teologicznym UJ w Krakowie, a potem w Innsbrucku, gdzie w r. 1915 uzyskal doktorat z teologii. Po paru latach pracy duszpasterskiej został mianowany w r. 1919 zastępcą profesora teologii moralnej na Wydziale Teologicznym UJ. W r. 1923 habilitował się $\mathrm{z}$ zakresu teologii moralnej na wspomnianym Wydziale przedstawiając pracę: „Niewolnictwo w nauce moralnej chrześcijaństwa”. Profesorem nadzwyczajnym został w r. 1928, a w dziesięć lat później profesorem zwyczajnym. W $1939 \mathrm{r}$. był aresztowany wraz z profesorami UJ i wywieziony do obozu $\mathrm{w}$ Sachsenhausen. Po powrocie $z$ obozu pełnił 
obowiązki administratora parafii w Dziekanowicach uczestnicząc równocześnie w tajnym nauczaniu. Gdy w r. 1945 otwarto Wydział Teologiczny UJ ks. prof. Wicher wrócił na katedrę teologii moralnej. Kiedy w r. 1954 zwinięto Wydział Teologiczny UJ podjął wykłady na Akademii Teologii Katolickiej w Warszawie. Po przejściu na emeryturę wykłada nadal teologię moralną w Krakowskim Seminarium Duchownym.

Omawiając działalność ks. prof. Wichra Ks. Kardynał wyróżnił jego twórczość naukową i pracę pedagogiczną. Swe zainteresowania naukowe skierował Jubilat najpierw ku dziedzinie dziejów teologii moralnej w Polsce, opracowując najwybitniejszych moralistów polskich z 17 w. (Makowski, Śmigielski, Mościcki). Równolegle z badaniami historycznymi podją ks. prof. Wicher w swej pracy naukowej tematykę aktualnych problemów chrześcijańskiego życia moralnego. Zajmował się m.in. etycznymi granicami sportu, problematyką etyczną życia seksualnego i małżeńskiego oraz alkoholizmem. Oceniając dorobek naukowy Jubilata Ks. Kardynał przytoczył charakterystykę twórczości ks. Wichra napisaną przez ks. prof. dra Konstantego Michalskiego w r. 1936 w związku z postulatem nominacji na profesora zwyczajnego. W rozprawach swych ,udowodnił autor, że potrafi z przeszłości wydobywać zapomnianych naszych moralistów, ażeby wskazać ich żywy związek z ówczesnymi prądami. Jeśli te rozprawy wskazują na zdolność ujęcia zagadnień moralnych w perspektywie historycznej, to drugi szereg rozpraw dowodzi, że ks. prof. Wicher zwraca przede wszystkim uwagę na życie współczesne, ażeby wynurzające się $\mathrm{z}$ niego zagadnienia oświetlić w sposób samodzielny z wyżyny etyki chrześcijańskiej” (...). ,Jak sama ilość rozpraw wskazuje na rozpiętość zainteresowań, tak tematy dowodzą rozmaitości przedmiotów obserwacji. Obserwacja życia współczesnego z jednej strony, a $z$ drugiej strony naukowe jego oświetlenie przez sprowadzenie do pewnych zasad i osądzenie go znowu z ich wyżyny, dowodzi syntetycznego i pewnego opanowania współczesnej rzeczywistości moralnej. Toteż sąd ks. prof. Wichra w wielu wypadkach uchodzi za miarodajny. Na uwagę specjalną zasługuje jego referat o metodach prowadzenia seminariów naukowych z dziedziny teologii moralnej, dając pewne wskazówki profesorom seminariów."

Wyrazem działalności dydaktycznej ks. prof. Wichra są bardzo liczne prace magisterskie i doktorskie pisane pod jego kierunkiem. Na uwagę zasługuje, że w doborze tematów prac dawanych studentom Jubilat lansował nowy kierunek badań z dziedziny socjologii moralności, wyprzedzając w pewnej mierze swoją epokę. Dopełnieniem obrazu działalności pedagogicznej ks. prof. Wichra są całe pokolenia kapłanów duszpasterzy i spowiedników przez niego formowanych.

$\mathrm{Na}$ zakończenie swego przemówienia Ks. Kardynał zwrócił się do Ju- 
bilata $\mathrm{z}$ wyrazami uznania i podzięki za zasługi dla Kościoła w Polsce, a zwłaszcza Archidiecezji Krakowskiej, wyrażając równocześnie serdeczne życzenia dalszej owocnej pracy.

Z kolei ks. Stanisław Smoleński przedstawiając zarys dziejów teologii moralnej na Akademii Krakowskiej wskazal na ks. Jubilata jako na wiernego kontynuatora tych chlubnych tradycji. Cecha charakterystyczna myśli teologiczno-moralnej profesorów Almae Matris Jagiellonicae to przede wszystkim otwarcie na aktualne problemy moralne. Ten znamienny rys odszukać możemy nie tylko w twórczości naukowej ks. prof. Wichra, ale i w pracach ukształtowanych przez niego uczniów. Konkretnym świadectwem tego jest Księga pamiątkowa. Zawiera ona (tymczasem $\mathrm{w}$ formie maszynopisu) zbiór artykułów $\mathrm{z}$ zakresu teologii moralnej, napisanych przez tych, dla których ks. prof. Wicher był profesorem, promotorem lub recenzentem pracy habilitacyjnej.

Następnie w imieniu świeckich profesorów UJ, dawnych kolegów księdza Jubilata, głos zabrał prof. dr Władysław Szafer. Podkreślił on szczególnie gorliwą i ofiarną troskę ks. prof. Wichra o dobro Uniwersytetu Jagiellońskiego i całej studiującej młodzieży, która ujawniła się specjalnie w okresie współpracy prof. Szafera jako rektora UJ z Jubilatem, wówczas dziekanem na Wydziale Teologicznym.

W imieniu KUL-u serdecznie życzenia Jubilatowi złożył ks. dziekan dr Władysław Poplatek, a w imieniu ATK - w zastępstwie chorego ks. dziekana St. Olejnika - ks. adiunkt dr Jan Pryszmunt.

Ostatni zabrał głos ks. Jubilat dziękując w serdecznych słowach za wszystkie wyrazy uznania i życzliwości.

W uroczystości jubileuszowej wzięli udział poza J. Em. Ks. Kard. K. Wojtyłą księża biskupi Wilhelm Pluta, Józef Rozwadowski, Stefan Bareła, Julian Groblicki, Jan Pietraszko; Kapituła Metropolitalna Krakowska; profesorowie Wydziałów Teologicznych i Seminariów Duchownych, a w szczególności profesorowie teologii moralnej z całej Polski, którzy uczestniczyli w ogólnopolskiej sesji poświęconej Humanae vitae. Uroczystość jubileuszową zaszczycili również swą obecnością profesorowie UJ dawni koledzy Jubilata i współwięźniowie z Sachsenhausen.

Bp. Stanisław Smoleński - Ks. Tomasz Chmura 